\title{
Assessment of Tourist Visitation and Host Communities' Participation in the Management of Selected Ecotourism Destinations in Nigeria
}

\author{
*Ijeomah, H.M., Okoli, C.I.C. \\ ${ }^{1}$ Department of Forestry and Wildlife Management, Faculty of Agriculture, University of Port \\ Harcourt, Rivers State, Nigeria \\ ${ }^{2}$ Department of Hospitality and Tourism Management, Imo State University, Imo State \\ *henryijeomah@yahoo.com, henry.ijeomah@uniport.edu.ng
}

\begin{abstract}
Several efforts have been made by tourism institutions in Nigeria concerning identification of new tourism attractions but the level of patronage and host communities' participation in many age old ecotourism destinations are yet to be ascertained. The study was therefore conducted to assess the level of tourist visitation and host communities' involvement in tourism in selected destinations in Nigeria. Data for the study were collected from Oguta Lake destination, Okomu National Park and Farin Ruwa Waterfall through personal interviews, structured questionnaire, observation and administrative records. The first set of questionnaire was randomly administered to selected number of tourist respondents in each destination. The second set was administered to officials while the third set of questionnaire was administered to household representatives who have lived in the community for a minimum period of 15 years. Data obtained were analysed using descriptive statistics in form of frequencies, percentages and tables with line graph (trend graph). Visitations of tourists to selected destinations have been unsustainable. Household involvement in tourism management was rated low in the destinations by all respondents (100\%). All household respondents from Farin ruwa waterfall destination $(100 \%)$ claimed to have derived some benefits from the management of the park. However, all household respondents (100\%) in the three destinations were not satisfied with the level of benefits derived from the sites. Visitors to Okomu national park and Farin ruwa waterfall considered trips to the destinations hectic but never regretted for visiting the destinations due their interesting and exciting experiences. Level of host community's awareness of the ecodestinations as tourism sites was rated high by all respondents (100\%). Provision of adequate infrastructure, tourism facilities, effective security services, consistent awareness and good management will stabilise tourists' visitation to destinations and stimulate the empowerment of host communities.
\end{abstract}

Keywords: Farin Ruwa waterfall, Oguta lake, Okomu national park, ecotourism, visitation trend

\section{INTRODUCTION}

Tourism has been adopted as a means for revenue generation and poverty alleviation in many countries Ijeomah 2007. However, the effectiveness of tourism in poverty alleviation can only be achieved when the money spent by tourists trickles down to households in tourism host communities (Ashley, 2000; Shah, 2000; Ashley et al., 2000, Ijeomah and Edet, 2011). Impact of tourism on the host communities also depends on availability of tourists, the expenditure pattern of visitors (Ijeomah and Herbert, 2012) and the style of destination management (Ijeomah, 2012). The effectiveness of tourism in job creation in many nations including least developed countries in the face of consistent increase in global level of unemployment has made tourism development a priority project for many governments. Many efforts have therefore, been made towards identification and development of tourist attractions, and awareness is consistently created concerning new eco destinations but the level of community participation and tourists visitation to age - old destinations are yet to be ascertained. Knowledge of trend of visitation, type of visitors and activities desired by tourists are very vital in determining potential profitable ventures which households can embark upon (Ijeomah and Ayodele, 2009). Packaging of activities or investing in projects (by either management or households) that are of less interest to tourists will attract little or no patronage, and may discourage community members from participating in tourism. It is very difficult for tourist destination management to offer direct employment to every member of the host communities, however, opportunities could be created where people become informally employed. This form of employment could be quite profitable but 
the level of income generation differs with destination and activity. This study therefore evaluates the trend of tourist visitation; experience and perceptions in selected ecotourism destinations in Nigeria; and assesses host communities awareness level of sites as tourism destinations coupled with participation and benefits derived from tourism business.

\section{Methodology}

\section{Study Area}

\section{Okomu National Park}

Okomu national park (ONP) is located in Edo State, Nigeria. It lies on latitude $6^{0} 21^{`} \mathrm{~N}$ and longitude $5^{0} 13^{`} \mathrm{E}$ (Inahoro, 1991).The park covers a land area of $212 \mathrm{~km}^{2}$ (National Park Service, 2009). The park is located in Ovia South-west local government, Edo State, Nigeria (Figure 1a). The park has four ranges which are; Julius creek range, Iguowan range, Arakwan range and Babui creek range. The topography of the park ranges between 30 and $60 \mathrm{~m}$ above sea level. The climate of Okomu is tropical, with well-marked rainy and dry seasons. The mean annual rainfall is $2100 \mathrm{~mm}$ and the mean monthly humidity is between $30.2 \%$ and $65 \%$ during the afternoon (Aremu et al., 2012). Okomu National Park (ONP) is the smallest national park in Nigeria. It was selected for this study as a wildlife park in southern Nigeria with endemic species and more developed tourism facilities than the two other national parks in southern Nigeria (Old Oyo and Cross River national parks)

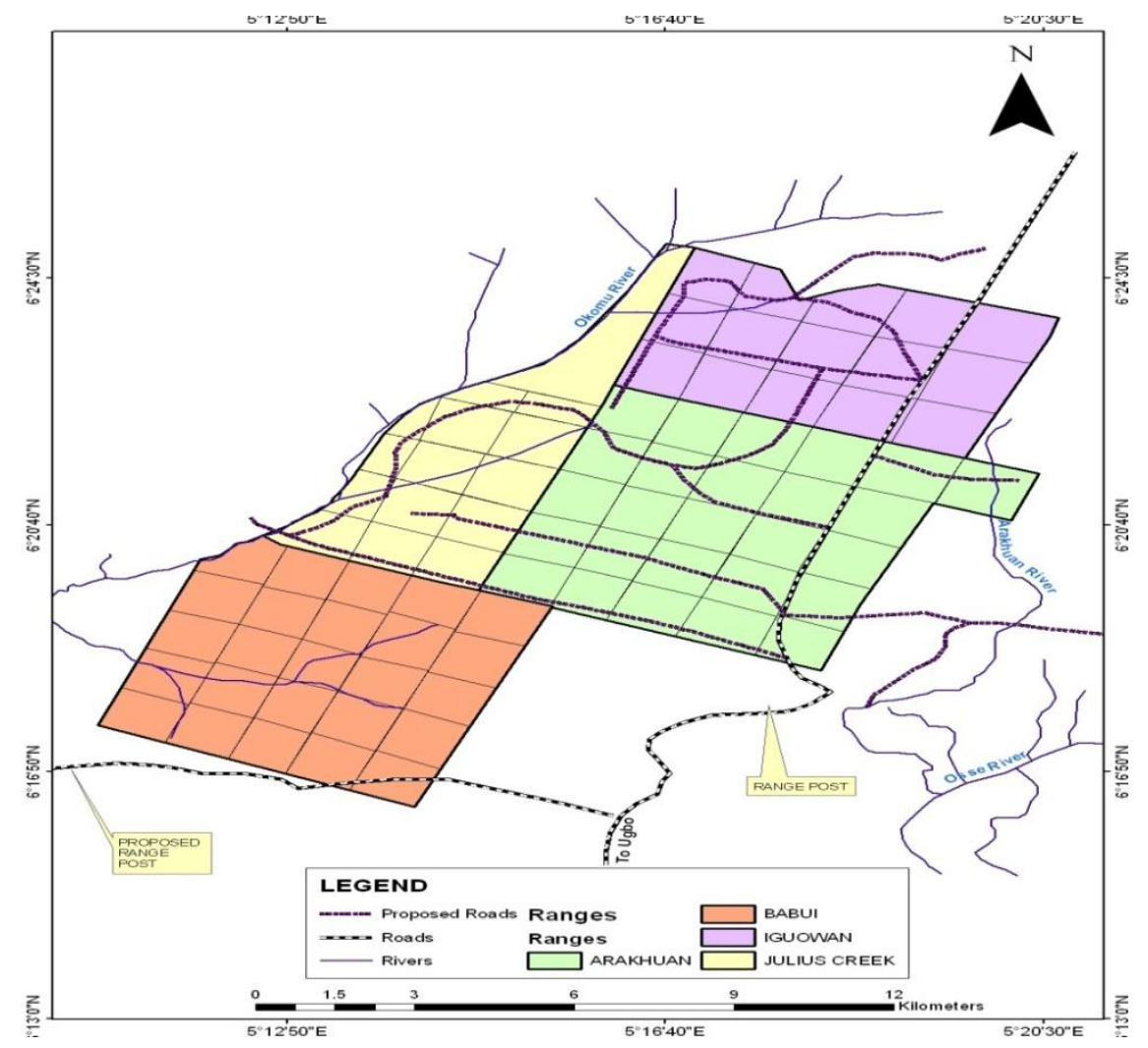

Figure1a. Map of Okomu National Park in Edo State, Nigeria Showing the Ranges

Source: Ijeomah et.al. (in Press)

\section{Oguta Lake}

Oguta Lake (OL), one of the Ramsar sites in Nigeria is located in Oguta local government area of Imo State (Figure 2a). It lies between latitude $5^{0} 41^{1}$ and $5^{0} 44^{1} \mathrm{~N}$ and longitude $6^{0} 56^{1}$ and $6^{0} 45^{1} \mathrm{E}$ of Greenwich (Ita et al., 1985). It is a natural lake with surface area of $1.80 \mathrm{~km}^{2}$ at peak flood and maximum depth of $7.00 \mathrm{~m}$ during raining season and mean depth of $5.50 \mathrm{~m}$. The lake is fed mainly by Njaba and Obana Rivers and empties itself into the River Niger drainage system through River Orashi. Oguta Lake has 39 species of fish (Ita et al., 1985). Oguta lake is one of the largest lakes in South Eastern Nigeria. The high diversity of the Ichthyofauna in the lake is attributed to its intimate contact with three rivers, one of the rivers (River Orashi) joins the River Niger known to be rich in fish fauna (Nwadiaro, 1989). 


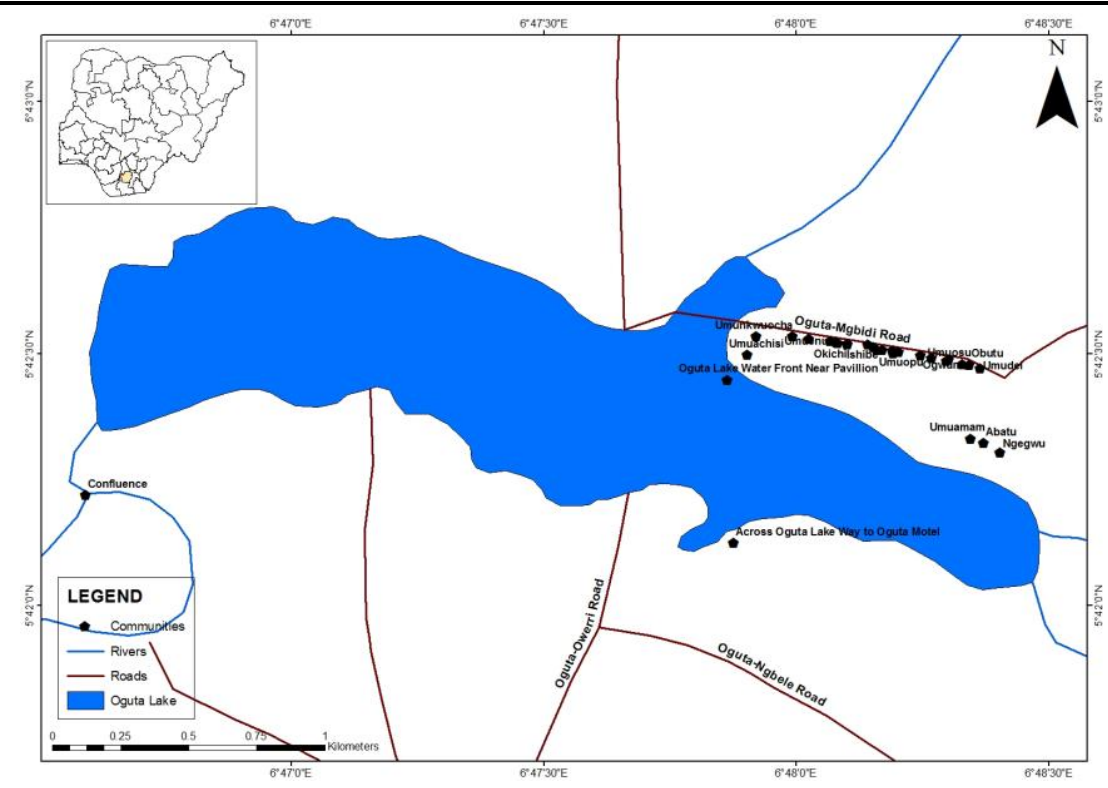

Figure2a. Map of Oguta Lake Showing the Locations of Oguta Villages around the Lake in A 'C' Shape

Source: Ijeomah et.al. (in Press)

\section{Farin Ruwa Waterfall}

Farin Ruwa Waterfall (FWF) is located located on latitude $09010^{1}$ and longitude $08045^{1}$ in Marhai Forest Reserve (Agbu, 2000) of Farin Ruwa Development Area. The entire Forest Reserve is $53.79 \mathrm{~km}^{2}$ and looks like a hollow surrounded by range of unequal hills that are uniformly arranged. On crossing the tollgate to Farin Ruwa, one descends to the iron gate through nineteen flat cemented staircases of $27.42 \mathrm{~m}$ by $0.76 \mathrm{~m}$ - the only passage through the closest stream to the waterfall (Ijeomah and Alao, 2007).The water has its source in Bokkos, Plateau State but is seen gushing out from a point in Masenge Community. The course of the river is only visible from a sharp turning point where it splashes due to the alignment of the rock basement. Simply put, water is just seen falling from a height of 150 meters and width of 50 meters into a rocky basin (Tourism guide, 2004; Ministry of Tourism and Culture, 2006).

The entire vicinity of the basin looks misty as a result of water vapour which saturates the environment consequent upon the splash. This was the origin of the name "Farin Ruwa" meaning white water. .

\section{Population of Study}

The operators of the three selected sites: Okomu national park, Oguta lake destination and Farin Ruwa Waterfalls; households in the host communities and tourists to these sites form the population of the study.

\section{Sample Unit}

These three selected sites represents ecotourism destinations in Nigeria as it covers wildlife based parks and wilderness areas; lakes and waterfall with varied ecosystems and land forms.

\section{Sample Size}

To determine the sample size for known population as in the case of officials, the Bowley's Formula, otherwise known as the Yaro Yamani Formula (Mac' odo 2002) for sample size determination was used. The formula is given as:

$$
\mathrm{n}=\frac{\mathrm{N}}{1+\mathrm{N}(\mathrm{e})^{2}}
$$

Where $\mathrm{n}=$ sample size

$\mathrm{N}=$ population

$\mathrm{e}=$ level of significance 
To determine the sample size for households and tourists, Owen and Jones cited by Yamani (1961) (probabilistic situation) was used as:

$$
\begin{aligned}
& \mathrm{n}=\mathrm{Z}^{2}(\mathrm{Pq}) / \mathrm{e}^{2} \\
& \text { Where } \mathrm{n}=\text { sample size } \\
& \mathrm{Z}=\mathrm{Z}-\text { value }=1.96 \\
& \mathrm{P}=\text { probability of success } \\
& \mathrm{q}=\text { probability of failure } \\
& \mathrm{E}=\text { error term or Tolerance error }
\end{aligned}
$$

\section{Research Instrument}

Information for this study were collected through personal observation, review of administrative records and administration of three sets of questionnaires

\section{Sampling Procedure}

The first set of questionnaire was randomly administered to selected number of tourist respondents in each destination based on the sample size (Table 2a).The second set of questionnaires was also administered to officials of destinations (who have spent a minimum of three years with the tourism institution) based on the sample size (Table 2a). The third set of questionnaire was administered (in accordance with the sample size assigned to destinations) to household representatives who have lived in the community for a minimum period of 15 years (Table $2 a$ ).

Oguta community has 27 villages, which live around the lake forming a ' $\mathrm{C}$ ' shaped curve (Ijeomah $e t$ $a l$ in press). Based on their location as guided by the " $\mathrm{C}$ " shape, the villages were divided into three groups of 9 villages each as listed in the table below:

Table1a. Division of Villages in Oguta Community into three Groups

\begin{tabular}{|l|l|l|}
\hline Group 1 & Group 2 & Group 3 \\
\hline Ngegwu village & Ogwuma village & Umunarukwu village \\
\hline Abatu village & Umuopu village & Okichi village \\
\hline Umuama village & Umuigbovillage & Umunku village \\
\hline Umudei village & Umunsohia village & Umukwukumoshi village \\
\hline Obutu villge & Umuayata village & Umuenu village \\
\hline Umuosu village & Umuorima village & Amaozoa village \\
Umutoguma village & Umuenemaya village & Umuduruowugu village \\
\hline Obuagwa village & Ishibe village & Umunkwucha village \\
Umuajuoma village & Amaozoa village & Umuachishi village \\
\hline
\end{tabular}

Source: Field survey, 2015

Two groups (1 and 2) were randomly selected and the questionnaire was randomly administered to respondents from 1 and 2. Personal interviews were also conducted with experienced individuals who have lived in Oguta for more than 15 years; and managers and owners of hotels and restaurants that have lasted for more than 15 years; the traditional ruler of Oguta community and members of the royal cabinet.

Based on $5 \mathrm{~km}$ closeness to Okomu National Park, 5 communities were selected. These communities are: Igwanfole, African Timber and Plywood (AT\&P), Iyayi, Iguowan, and Udo. Information on visitation trend was collected from administrative records of the park. In-depth interview was conducted with experienced staff members; including the Head of Department of ecotourism, tour guide, research officers, and knowledgeable household representatives and tourist respondents to complement information obtained through questionnaire and administrative records.

In the case of Farin Ruwa Waterfall, the third set of questionnaire was administered to selected household representatives in Marhai, Masenge and Kwara based on pre-determined sample size (Table2a). Indepth interview was equally conducted with experienced staff of Nasarawa State Ministry of Tourism and Culture including the Director and deputy Director of the ministry and tour guards.

\section{Determination of Sample Size for Tourists}

Out of 18 questionnaire administered to tourists during pre - texting, 17 were positive while only 1 was negative. Applying Owen and Jones formula as cited by Yamani (1961): 


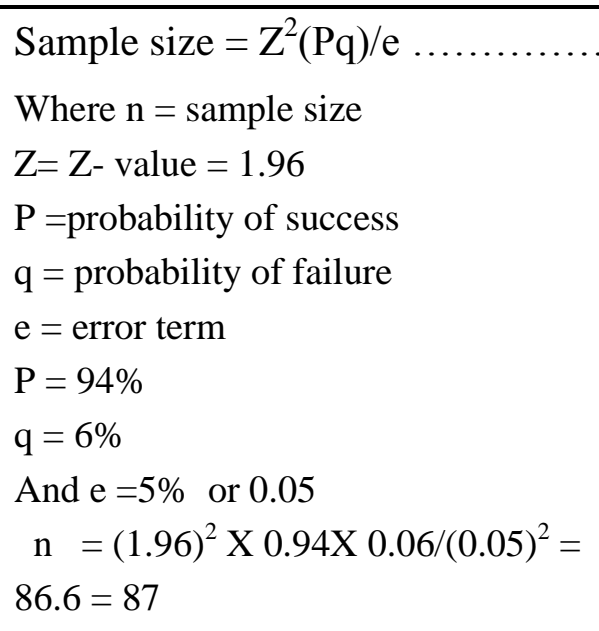

However, Anyanwu (2000) emphasized that the greater the sample size the better the precision of the research. Instead of 87 the sample size for tourists was increased to 180 (Table 2).

\section{Determination of Sample Size for Officials}

Yaro Yamani Formula (Mac' odo 2002) for sample size determination was used. The formula is given as:

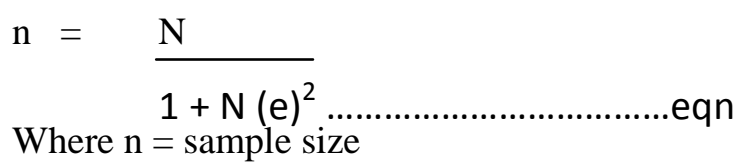

$\mathrm{N}=$ population

$\mathrm{e}=$ level of significance

For Farin ruwa waterfalls:

$39 / 1+39(0.05)^{2}=$

$1+39(0.0025)$

$=39 / 1.0975$

$=35.5$

$=36$

For Okomu national park:

$45 / 1+45(0.0025)=45 / 1.1125=40.4$

$=40$

For Oguta Lake destination:

$467 / 1+467(0.0025)$

$=467 / 2.1675$

$=215.45$

$=215$

Sample size for management $=36+40+215=291$

\section{Sample Size for Households}

During pre - texting a total of 30 copies of questionnaire were distributed to households' representatives in the host communities of the destinations. A total of 28 showed positive or success while 2 were negative. Using Yamani (1961) formula the sample size was calculated:

$\mathrm{P}=93.0 \%, \mathrm{q}=0.7 \%$ and $\mathrm{e}=5 \%$

This translates to:

$(1.96)^{2} \times 0.93 \times 0.07 / 0.0025$

$=0.25008816 / 0.0025=100,035$

$=100$ 
Ijeomah, H.M. \& Okoli, C.I.C.

Table2a. Proportional Allocation of Questionnaire to Respondents in Destinations

\begin{tabular}{|c|c|c|c|c|}
\hline $\begin{array}{c}\text { Sets of } \\
\text { questionnaire }\end{array}$ & Destination & $\begin{array}{c}\text { Number of } \\
\text { Questionnaire } \\
\text { administered } \\
\end{array}$ & $\begin{array}{c}\text { Number of } \\
\text { Questionnaire } \\
\text { retrieved }\end{array}$ & Total used \\
\hline \multirow[b]{3}{*}{ 1. Tourists } & Oguta lake & 60 & 57 & 57 \\
\hline & Okomu national park & 60 & 54 & 54 \\
\hline & Farin Ruwa falls & 60 & 58 & 58 \\
\hline Total & & 180 & 169 & 169 \\
\hline \multirow{3}{*}{ 2. Officials } & Oguta lake & 215 & 210 & 210 \\
\hline & Okomu national park & 40 & 32 & 32 \\
\hline & Farin Ruwa falls & 36 & 32 & 32 \\
\hline Total & & 291 & 274 & 274 \\
\hline \multirow{3}{*}{ 3. Households } & Oguta lake & 34 & 32 & 32 \\
\hline & Okomu national park & 33 & 31 & 31 \\
\hline & Farin Ruwa Waterfalls & 33 & 31 & 31 \\
\hline Total & & 100 & 94 & 94 \\
\hline
\end{tabular}

Source: Field survey, 2015

\section{Method of Data Analysis}

Data obtained were analysed using descriptive statistics in form of frequencies, percentages, pie chart, bar chart and tables with line graph (trend analysis).

\section{RESULT}

\section{Trend of Visitation}

Results on trend of tourist visitation in the three destinations are presented in figures 1 to 3 and table 1. Oguta Lake fluctuated and remained static between 2003 and 2010, then increased gradually in 2011 and 2012 before decreasing from 2013 (Figure 1).Trend of tourist visitation in Farin ruwa waterfall increased to 2005 and decreased continuously till 2013 (Figure 2). Visitation trend in Okomu national park is consistently fluctuation (Figure 3). As presented in table 1, majority of the respondents indicated that the visitation trend of tourists in Okomu national park (56.25\%) and Oguta lake $(53.34 \%)$ are fluctuating while that of Farin ruwa waterfall is decreasing (68.75).

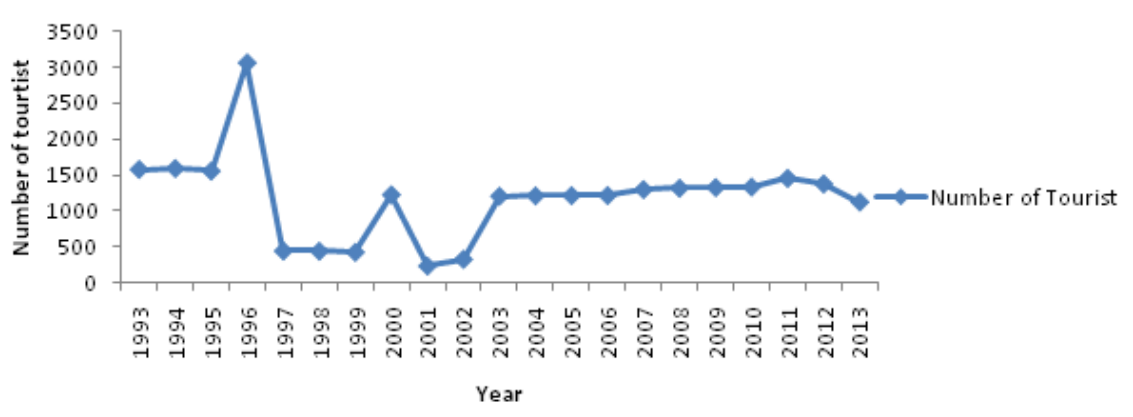

Fig1. Trend of Tourist Visitation in Obana Motel within Oguta Lake Environment

Source: Field survey, 2015

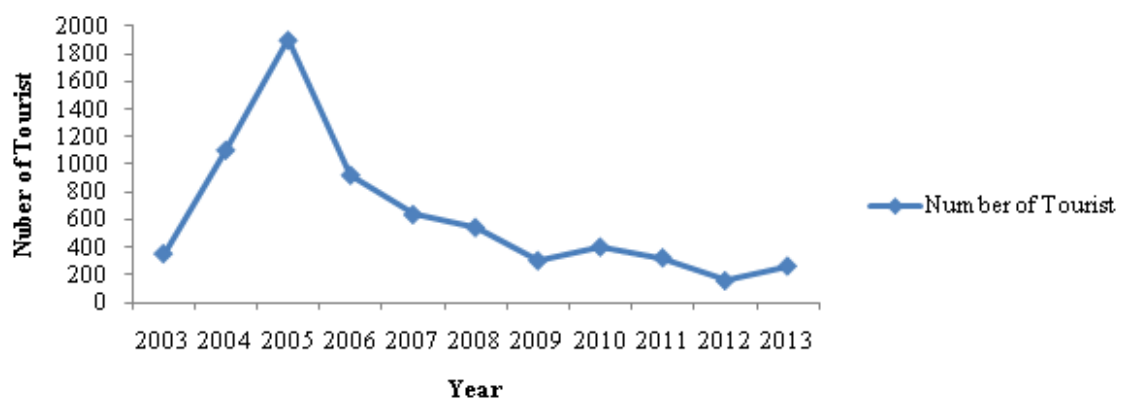

Fig.2. Trend of Tourist Visitation in Farin Ruwa Fall

Source: Field survey, 2015 


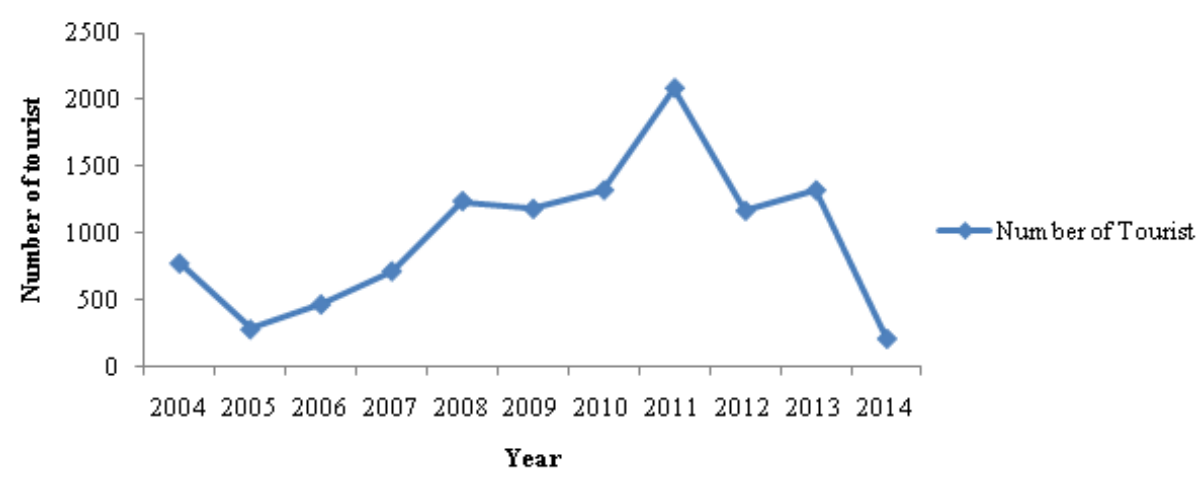

Fig3. Trend of Tourist Visitation in Okomu National Park

Source: Field survey, 2015

Table1. Assessment of Tourist Visitation in Ecodestination

\begin{tabular}{|l|l|l|l|}
\hline Destination & Trend visitation & Frequency & Percentage \\
\hline Okomu & Increasing & 9 & 28.13 \\
National & Static & 0 & 0 \\
Park & Decreasing & 5 & 15.62 \\
& Fluctuating & 18 & 56.25 \\
\hline Oguta lake & Increasing & 13 & 6.19 \\
& Static & 53 & 25.24 \\
& Decreasing & 32 & 15.23 \\
& Fluctuating & 112 & 53.34 \\
\hline Fari ruwa fall & Increasing & 3 & 9.38 \\
& Static & 0 & 0 \\
& Decreasing & 22 & 68.75 \\
& Fluctuating & 7 & 21.87 \\
\hline
\end{tabular}

Source: Field survey, 2015

\section{Community Awareness of Site as an Ecodestination}

Results on host community awareness of site as ecodestination are presented in Table 2. Table 2 shows that all respondents $(100 \%)$ rated host community awareness of destinations as tourism site high.

Table2. Level of Host Community Awareness of the Ecodestination as a Tourism Site

\begin{tabular}{|l|l|c|}
\hline Variable & Frequency & Percentage \\
\hline High & 368 & 100 \\
\hline Low & 0 & 0 \\
\hline Medium & 0 & 0 \\
\hline
\end{tabular}

Source: Field survey, 2015

\section{Household Participation in Tourism and Benefits}

Results on household participation in tourism management in the destinations and level of benefits derived are presented in tables 3 to 7 . Table 3 shows that all the respondents (100\%) rated household involvement in tourism management low both in the formal and informal except in Oguta lake where households are privately involved in tourism activities. Table 4 shows that the highest form of benefit derived by households from Oguta lake is income generation (43.75\%) and all the respondents $(100 \%)$ are not satisfied with the level of benefit derived from the destination. Many benefits were indicated to have been derived from the management of Farin ruwa waterfalls, though all the respondents are not satisfied with the measure of benefits (Table 5). Majority of the respondents (51.61\%) indicated that they have not derived any benefit from the management of Okomu national park (Table 6). Those who have derived some form of benefits were not satisfied. According to majority of the households as presented in Table 7 host communities are not in control of the management of tourism destinations. 
Ijeomah, H.M. \& Okoli, C.I.C.

Table3. Host Communities Level of Participation in Tourism Management in Destinations

\begin{tabular}{|cl|l|l|}
\hline & Formal & Informal \\
\hline ONP & & 0 \\
& High & 0 & $31(100 \%)$ \\
\hline Low & $31(100 \%)$ & 0 \\
\hline High & 0 & $31(100 \%)$ \\
Low & $31(100 \%)$ & $32(100 \%)^{*}$ \\
\hline Oguta lake & 0 & 0 \\
\hline High & 0 & \\
\hline Low & 0 & \\
\hline
\end{tabular}

Source: Field survey, 2015

Table4. Benefits Derived by Households from Oguta Lake

\begin{tabular}{|l|l|l|}
\hline Benefits & Frequency & Percentage (\%) \\
\hline Source of income & 14 & 43.75 \\
\hline Infrastructural development & 9 & 28.12 \\
\hline Employment & 8 & 25.00 \\
\hline $\begin{array}{l}\text { Cultural heritage } \\
\text { If households are satisfied with the level benefits derived? }\end{array}$ & 8 & 25.00 \\
\hline Yes & 0 & 0 \\
\hline No & 32 & 100 \\
\hline
\end{tabular}

Source: Field survey, 2015

Table5. Benefits Derived by Households from Farin Ruwa Waterfalls

\begin{tabular}{|l|l|l|}
\hline Benefits & Frequency & Percentage \\
\hline Provision of secondary school & 31 & 100 \\
\hline $\begin{array}{l}\text { Graded the road and constructed culvert for six } \\
\text { streams to the fall }\end{array}$ & 31 & 100 \\
\hline Cottage hospital & 31 & 100 \\
\hline Police post & 31 & 100 \\
\hline Electricity & 31 & 100 \\
\hline Cultural heritage & 31 & 100 \\
\hline Popularisation of community & 31 & 100 \\
\hline Buildings with chalets & 31 & 100 \\
\hline $\begin{array}{l}\text { Lively community due to occasions hosted in the } \\
\text { destination }\end{array}$ & 31 & 100 \\
\hline $\begin{array}{l}\text { Sales during dam construction } \\
\text { If households are satisfied with the level benefits } \\
\text { derived? }\end{array}$ & 31 & 100 \\
$\begin{array}{l}\text { Yes } \\
\text { No }\end{array}$ & 0 & 0 \\
\hline
\end{tabular}

Source: Field survey, 2015

Table6. Assessment of Host Communities Benefits from Okomu National Park as Indicated by Household Respondent

\begin{tabular}{|l|l|l|}
\hline Benefits & Frequency & Percentage (\%) \\
\hline No benefit & 16 & 51.61 \\
Employments & 12 & 38.70 \\
Borehole water & 12 & 38.70 \\
Provides security & 5 & 16.12 \\
Income through sales of non-timber forest products & & \\
Provision of good roads & 3 & 9.67 \\
Mosquito nets & 1 & 3.22 \\
If households are satisfied with the level of benefits & 1 & 3.22 \\
derived? & & \\
\hline Yes & 7 & 22.58 \\
No & 24 & 77.42 \\
\hline
\end{tabular}

Source: Field survey, 2015 
Assessment of Tourist Visitation and Host Communities' Participation in the Management of Selected Ecotourism Destinations in Nigeria

Table7. Determining whether Host Communities are not in Control of the Management of Tourism Destinations

\begin{tabular}{|l|l|l|}
\hline Options & No. of respondents & Percentage \\
\hline Strongly agreed & 3 & 0.82 \\
\hline Agreed & 10 & 2.72 \\
\hline Disagreed & 215 & 58.42 \\
\hline Strongly disagree & 140 & 38.04 \\
\hline Total & 368 & 100 \\
\hline
\end{tabular}

Source: Field survey, 2015

\section{Expectation of Host Communities}

Results on the expectation of host communities from management of tourism sites are presented in table 8. Top on the list of household expectations from the management of Okomu national park as presented in table 8 is to involve indigenes in site management (100\%), followed by provision of electricity $(77.41 \%)$ and employment of members of the community. In the case of Oguta lake, all respondents (100\%) expect the management to provide infrastructures and security, maintain tourism facilities and construct a bridge across the lake. For Farin ruwa waterfall the major expectations are to build a new bridge across river Njiri, employ indigenes and make the site viable.

Table8. Expectations of Host Communities from Management of Ecodestination

\begin{tabular}{|l|l|l|l|}
\hline Destination & Expectation & Frequency & Percentage \\
\hline Oskomu & Involvement of indigenes in site & & \\
National & management & 31 & 100 \\
& Electricity & 24 & 77.41 \\
& Employment & 24 & 77.41 \\
& Scholarship & 20 & 64.51 \\
& School & 17 & 54.83 \\
& Borehole & 15 & 48.38 \\
& Good road network & 15 & 48.38 \\
& Good healthcare facilities & 13 & 41.93 \\
& Market & 9 & 29.03 \\
\hline Oguta lake & Provide infrastructures & 32 & 100 \\
& Construct a bridge across the & 32 & 100 \\
& maintain tourism facilities & 32 & 100 \\
& Provide security & 25 & 100 \\
& Create awareness & & 78.12 \\
& & 31 & 100 \\
\hline Farin ruwa waterfall & Build a new bridge & 31 & 100 \\
& Employ indigene & 22 & 100 \\
& Make the site viable & 19 & 70.96 \\
& Provide security & & 61.29 \\
\hline
\end{tabular}

Source: Field survey, 2015

\section{Tourists' Experience and Perceptions of Destinations}

Results on tourists'experience and perceptions of destinations are presented in tables 9 to 10. Table 9 shows that respondents to Farin ruwa waterfall had diverse experiences which include being interesting, hectic, enjoyable, exciting, wonderful and fascinating ones. All the respondents (100\%) from Okomu national park had hectic experience while $85.18 \%$ had interesting experience. None of the respondents from Oguta lake had hectic experience (table 9) as all the respondents indicated that they had interesting experience, followed by exciting experience (91.22\%). Majority of the respondents to Okomu national park, Oguta lake and Farin ruwa water fall agreed that they are satisfied with their experiences (Table 9).Table 10 shows that the respondents have diverse perceptions of the tourism sites. 
Ijeomah, H.M. \& Okoli, C.I.C.

Table9. Assessment of Tourist Experience in Ecodestinations

\begin{tabular}{|l|l|l|l|}
\hline Destination & Tourist experience & Frequency & Percentage \\
\hline FWF & Interesting & 58 & 100 \\
& Hectic & 58 & 100 \\
& Enjoyable & 58 & 100 \\
& Exciting & 58 & 100 \\
& wonderful & 58 & 100 \\
& fascinating & 58 & 100 \\
\hline ONP & Hectic & 54 & 100 \\
& Interesting & 46 & 85.18 \\
\hline \multirow{5}{*}{ OL } & Exciting & 43 & 79.62 \\
& Fascinating & 39 & 72.22 \\
& & & 100 \\
& Interesting & 57 & 91.22 \\
& Exciting & 52 & 89.47 \\
& Fascinating & 51 & 0 \\
\hline
\end{tabular}

Source: Field survey, 2015

Table10. Assessment of Tourist Perception of Ecodestination

\begin{tabular}{|l|l|l|l|}
\hline Destination & Perception & Frequency & Percentage \\
\hline FWF & Wonder of nature & 38 & 65.51 \\
& Home of nature & 32 & 55.17 \\
& Beautiful site & 21 & 36.20 \\
& Unique waterfall & 19 & 32.75 \\
& Very high waterfall & 15 & 25.86 \\
& Natural environment & 9 & 15.51 \\
\hline \multirow{3}{*}{ ONP } & Natural environment & 41 & 75.92 \\
& Rich park & 23 & 42.59 \\
& Home of nature & 9 & 16.66 \\
& Good environment & 7 & 12.96 \\
\hline \multirow{3}{*}{ OL } & Natural water & 48 & 84.21 \\
& Pure water & 43 & 75.43 \\
& Cool water & 42 & 73.68 \\
& Recreation water & 38 & 66.66 \\
& Relaxation place & 36 & 63.15 \\
& Wonder lake & 36 & 63.13 \\
\hline
\end{tabular}

Source: Field survey, 2015

\section{DisCuSSION}

\section{Trend of Visitation}

The visitation of tourists to Oguta lake destination was almost steady between 1993 and 1995, fluctuated and remained steady for about a decade (figure 1). The fluctuations cannot be unconnected with inadequacy of infrastructure, facilities and insecurity in the environment. Visitors always want to relax with cold drinks and refresh in air conditioned room (after sightseeing) especially during dry season but that is hardly achieved because of frequent power failure in the environment. The few hotels in the community hardly use their generators during the day as a strategy to save cost of petrol and diesel (for powering generators). It is only when visitors give the hotel operators money to fuel their generators that they use generators during the day. Notwithstanding that in many cases tourists sponsor the operation of these generators; other customers still buy cold drinks at a relatively higher price from the same operator - the hotel managers would always claim that generators were used to chill drinks. This altitude and fear of attracting extra cost discourages visitors from embarking on sightseeing, an act that can only be allowed during the day. Occasionally, the boats used for ferrying breakdown on the lake, causing tension to visitors especially those who cannot swim. The fact that the waterfronts are sometimes littered with waste materials and dung, makes the environment irritating and unattractive. The situation gives visitors a negative impression about Oguta Lake, and discourages some tourists from repeating visits. 
This is contrary to what obtained in the era of colonial master and other Europeans who discovered the lake in 1885 . Then, Oguta Lake was very popular and therefore cherished by many visitors. There were multitude of Europeans in Oguta who visited for business and tourism through ships as the lake has direct links with the Atlantic Ocean. During that period, the lake attracted people from many other parts of Nigeria, such as Patani, Warri, Abonnema, Bayelsa, Kalabari and Onitsha (as Oguta was the centre of oil palm trade in eastern Nigeria) who arrived in batches to carry palm oil for trading .

As a result of these, Oguta experienced boom in tourism until the time of the Nigerian civil war (in 1967) which lasted for three years. During the war, the palm oil factory established by Europeans was bombed by Nigerian soldiers as it was mistaken to be an arms factory. The foreign companies in Oguta community were relocated to other countries and other parts of Nigeria since one of their main business attractions to Oguta was destroyed. The departure of these foreign companies such as The Compagnie Francaise de l' Afrique Occidentale (CFAO), The Socie 'te 'Commerciale de l'Quest Africain (SCOA) and The United African Company (UAC) destabilized tourism in Oguta. The building of Oguta motel in 1977 increased visitation to Oguta lake destination. Oguta motel was established by Oguta community within the Oguta Lake vicinity through the support of the former East Central State Governor, Governor Asika Ukpabi (after his regime of 1967-1975). Oguta motel has 60 rooms and 20 parlours, that were big enough to accommodate visitors and their families together, with one of the largest golf course then in Nigeria. The motel attracted foreigners and other high class tourists in the country as the destination became a hotspot for playing golf, sightseeing and picnicking. The petroleum companies in Oguta also took the motel as a base where they lodged their executive staff members (for months) who were mostly expatriates. Between1966 and 1975 the government of the then eastern region was very supportive towards development of Oguta destination in terms of funding for provision of infrastructure unlike this present time.

The trend of tourism visitation in Obana motel, an age-old firm within the Oguta environment gives an insight of the present trend of visitation to Oguta destination (Figure 1). The trend shows that annual visitation which increased to 3000 in the 1990s suddenly declined to 335 between 1997 and 2000. The decline was caused by frequent arm robbery, kidnapping and occult activities which besieged the community. It was so serious then (between 1997 and 2000) that indigenes of the community became afraid of embarking on sightseeing around the lake environment with their visitors especially, foreigners. The perception of $34.78 \%$ of the respondents that visitation was increasing could be because of their previously experienced influx of tourists in Obana motel (table 1). Similarly, the Swan Hill Pioneer Settlement Museum located in North West Victoria, Australia, at inception attracted about 300,000 visitors, which reduced to 35,000, and later increased to 48,000 visitors in 2007 (Lade, 2010). Unlike the case of Oguta lake, Lade (2010) attributed the decline in visitation to the museum to competition from tourism industries in other places. It appeared to be static between 2012 and 2013.

Visitation trend of Okomu national park has been fluctuating but there was no case of being static for a long time (figure 2). The case of Okomu national park must have been affected by political situations in the country. A slightly different trend is experienced in Farin ruwa waterfall where visitation increased progressively from 400 to 2000 between 2003 and 2005 after which it decreased consistently till 2013 (figure 3). The decrease in visitation can be attributed to neglect by the Nasarawa State Government coupled with inadequate infrastructure and tourism facilities. The regime of Abdullahi Adamu supported tourism and therefore popularized Farin ruwa waterfall. This increased visitation to the site. In 2003 world tourism day was celebrated in Farin ruwa waterfall destination. Since 2008 till date no project or activity has been formally carried out in Farin ruwa waterfall destination by the Nasrawa State government.

\section{Period of Visitation}

Visitation to Oguta Lake is more during festive periods when so many activities and functions take place. Marriage ceremonies, Omerife festival, Christmas and Easter celebration are among the attractive ceremonies in Oguta. A lot of people return to Oguta during these periods through invitation for events or occasions. In the course of the season, the lake is advertised as a venue for some of the events such as the peace carnival held at the lake pavilion between December 29 and 30, 2013, which attracted about 50,000 persons. The festive periods are usually from December to February for Christmas and Valentine season, August to September for Omerife and Ogene festival. This agrees 
with Ijeomah et al (2011) concerning influx of people in eastern Nigeria during festive periods such as Christmas and Easter celebrations. Some visitors prefer visiting Oguta lake during the dry season when it is more convenient as there will be no case of flooding. The gun boat (relics of the Biafra boat bombed during the civil war) is clearly observed during the dry season as the water level becomes normal. Some tourists visit regularly in all season throughout the year while few visit during the rainy season for fishing and farming. Also in terms of time of visitation, unlike the Oguta Lake, the Pandam Wildlife Park is not visited during the rainy season because of the flooded nature of the park which hinders accessibility to the destination (Ijeomah and Emelue, 2009).

In the case of Okomu national park and Farin ruwa water fall visitation is mostly during dry season when the site could be more accessible as these two destinations are wilderness areas.

\section{Community Awareness, Participation and Benefits}

The level of community participation in tourism management especially at formal sector is low in all the destinations (table 2). It is only in Oguta lake destination that households are really involved in private management of tourism related businesses such as speed boat.

It is difficult for none indigenes of Oguta to participate in tourism businesses in Oguta lake.

The households in Oguta run all the commercial businesses operated in Oguta (such as hotel business, restaurant, bar business, ferrying business, roasting and marketing of fish, and commercial riding of bikes) to generate income. There are two functional hotels (the Blue Waters Hotel and the Lake View Hotel); a guest house and one motel (Obana Motel), apart from the Oguta Motel. There are also 40 joints, restaurants and bars (all owned by Oguta indigenes) and that functions throughout the year. The fact that these joints and restaurants are in operation throughout the year shows that they are always patronized by visitors. Tourists frequently consume pepper soup and drinks in these restaurants and joints. The fact that these restaurants and joints sell at cheaper rates than the hotels makes them to have more patronage than the hotels. More so, most visitors do not always lodge in hotels, since they do not stay overnight. Many visitors prefer lodging in Owerri, Imo State, where there are more standard hotels.

The ferrying facilities such as speed boats are about 45 in number and are owned by the community members. It is only the pontoon that is managed by Imo state government. Other 4 boats that operate in the lake are owned by the marine police while Imo State Ministry of Transport and Tourism also have two boats that are used for ferrying. Households always organise events such as cultural festivals, marriage ceremonies, second burial ceremony, chieftaincy conferment and birthday celebration which entails inviting visitors. The peace carnival held in December, 2013 in Oguta, attracted many visitors who came and were taken round the lake and community for sightseeing. Similar case was reported in Rwanda, whereby the communities around the Akagera National Park have community camp sites as enterprise, craft centres, cultural centre, and the households were involved in economic activities (Ashley and Roe, 1998).

There are a lot of age- old cultural festivals organised by Oguta community that draws crowd to Oguta lake. These include the Omerife festival, Ogene Nkirika 1 and 2, the Age grade dance and others such as the masquerade parade. This is done in such a way that different age groups in that community participate in their best and colourful traditional attire dancing round the village singing in their local dialect. The masquerade parade is performed when masquerades from different villages emerge to display to entertain people. For instance, during the Peace Carnival held in December 2013, there were 25 masquerades from different villages and from other communities in Imo State that paraded in the lake destination. About 20,000 people that visited to watch the parade were from both Oguta and other parts of the Nigeria especially Imo State. The Ozuruimo cultural festival organised by the Imo state government is performed every two years in Oguta lake pavilion. Different communities from Imo state attend to showcase their various cultural dances while the Oguta community also showcases their boat regatta (on the lake) and Arugu dance (on land at the pavilion) displaying their prawn, shark and crocodile costumes. The benefits the households derive from Oguta lake are mainly in form of income generation (table 3). Income is generated from various commercial activities such as hotel and restaurant business, video coverage and photography (to cover events); from rentals of chairs, canopies and other material. Revenues are as well generated from sand dredging. Similarly, in Akagera National Park, the community around the park generate revenue from restaurant business, guest house, craft shops and camping site (Ashley and Roe, 1998).The benefits (income) derived from 
tourism in Oguta are mostly generated during the festive periods (table 3). This is because a lot of people visit Oguta en mass either for Christmas, Easter, Omerife or other events. Although throughout the year, the households generate income from various commercial activities but more are generated during the festive periods. The activities that generate income for the households are ferrying business, photography and video coverage, hotel and restaurant business, rentals, fishing, farming, and sale of different items including food and drinks. This partly agrees with the findings of Ijeomah and Ayodele (2009) in ecodestinations in Plateau State.

On community basis the host communities to Farin ruwa waterfall have relatively benefitted more than their counterparts in other destinations (table 4). Some of these benefits include, building of secondary school, grading of the access road that leads to the destination and subsequent construction of culverts for six streams to the fall (though they were later washed away), cottage hospital, police post, electricity, building of chalets, popularisation of the community, lively community caused by frequent invents hosted in the destination, building of lodges with 26 chalets and increased sales of local products such as palm wine during dam construction. Oguta community generate revenue through renting of the lake pavilion for ceremonies. Nevertheless, all the household respondents and those from Oguta lake interviewed were not satisfied with the level of benefit derived from tourism. Majority of those from Okomu national park stated that no benefit was derived from the destination while others were not also satisfied with the level of benefit derived from the management of the destinations (table 5). The three tourism destinations are managed by either state or federal government (table 6). Ownership and management of private ecotourism destination is yet to become a reality in Nigeria.

\section{Expectation of Host Communities}

Respondents from Oguta community were more concern in ensuring that the destination is made viable (table 7). This is because respondents from Oguta have been benefitting from the informal employment of tourism and therefore expect the destination management make the business viable for more beneficial opportunities. In addition to the expectation of Oguta respondents, the ones from Okomu national park and Farin ruwa expect the destinations to employ indigenes of the community. This is because majority of these respondents have not individually benefitted from tourism operations. Host communities expect destination managers to involve indigenes in the management of destinations, provide infrastructures and make destinations viable for tourism boom.

\section{Tourist Experience and Perception of Ecodestination}

Notwithstanding the numerous challenges faced by tourists in the study areas, which all the tourist respondents in Okomu national park and Farin ruwa water fall described as being hectic (table 8), yet majority of tourist respondents are satisfied with their experiences (table 9). None of the respondent from Oguta lake claimed to have a hectic experience because the destination is easily accessible. Okomu national park and Farin ruwa water fall are in wilderness areas and therefore difficult to access. Visitors pass through difficulties to access the sites but easily forget their hectic experiences after accessing the destination due to the uniqueness of the natural environments.

\section{Conclusion}

The tourism sites have not really experienced consistent growth. One of the best security measures in ecodestinations is achieved through involvement of households from host communities in such a way that they sustainably derive 'adequate benefits.' They will always ensure that their source of benefit is secured. These benefits could be through direct employment or provision of social amenities. In terms of social amenities, Masenge being the host communities of Farin ruwa waterfall has benefitted most, although culverts constructed therein were not durable. On individual basis households from Oguta have derived more benefits through their private businesses that get patronage from markets created by tourism. Integration of the culture of host community into tourism is experienced more in Oguta lake destination than the other two sites. Integration of culture, however should be properly planned in such a way that it will not erode biodiversity conservation. Ease of access to destination is higher in Oguta lake because the environment is used for many occasion. Similar relatively high visitation was once experienced in Farin ruwa water fall when the playground was used as venue for many events. It is not ecologically acceptable to allow a national park like Okomu to be used in similar manner as venue for many noisy events to avoid anti conservation practice - the number of tourists to a national park should be regulated. 


\section{RECOMMENDATIONS}

In order to promote tourism and enhance tourists' visitation to these destinations, there is need for consistent creation of awareness about the destinations. Besides, the households need to be enlightened in order to increase their participation in tourism management. More cultural and tourism activities such as carnivals, beauty pageant, water skiing, inter village boating and swimming competitions can be introduced in both Oguta lake and Farin ruwa waterfall destinations. The guinea corn festival of Masenge community should also be incorporated into the tourism package of Farin ruwa waterfall.

In order to meet the communities' demand for potable water, it is recommended that the management of Okomu national park should assist households by providing boreholes. There is also the need for good road network to facilitate easy movement in and out of the communities. Okomu national park should assign more than one tour guide to a fairly large group of tourists in order to enhanced tourists' experience.

\section{REFERENCES}

Agbu, V.B. (2000). Marhai Forest Reserve., Bureau for Lands, Survey and Town Planning, Lafia, Nasarawa State

Aremu, O. T., Emelue, G. U., Osayimwen, F. E. and Obasogie, F.O. (2012). Estimate of habitat quality of White throated monkey in Okomu National Park, Nigeria. Nigeria Journal of Agriculture, food and environment, 8(1), 20-21.

Anyanwu, A. (2000). Research Methodology in Business and Social Sciences. Canun Publishers, Owerri, 259pp.

Ashley, C. and Hussein, K. (2000). Assessment Experience of the African Wildlife Foundation in East Africa Overseas Development Institute, London

Ashley, C. and Roe, D. (1998). Enhancing community involvement in wildlife tourism: Issues and challenges. Wildlife and Development Series No. 11. IIED, London

Ashley, C.Boyd, C. and Goodwin, H. (2000). Pro-poor tourism: Putting poverty at the heart of the tourism Agenda. Overseas Development Institute. London. 13pp.

Ijeomah, H. M. and Ayodele, I. A.( 2009).Assessment of Revenue generation Avenues in Ecotourism Destinations of Plateau State, Nigeria. African Research Review, 3(4):441-452.

Ijeomah, H. M (2007). Impact of Tourism on Perceived Poverty Alleviation in Plateau State, Nigeria, PhD thesis. Department of Wildlife Management and Fisheries, University of Ibadan, Oyo State, Nigeria. 301pp.

Ijeomah, H. M and. J. S. Alao (2007). Assessment of Ecotourism Development at Farin Ruwa Waterfall in Nasarawa State, Nigeria. Journal of Production Agriculture and Technology (PAT) 2(3), 162-174.

Ijeomah, H. M. and Emelue, G. U. (2009). Tourism Management and Sustainability Resources Utilization in Pandam Wildlife Park of Plateau State, Nigeria. Journal of Sustainable Development in Africa, 11(2), 206-222

Ijeomah, H.M., Alarape, A.A. and Ogogo, A. U. (2011). Ecotourism Potentials of

Plateau State, Nigeria: A Monitoring survey. Asia Pacific Journal of Tourism Research 16(2),153 167

Ijeomah H.M. and Edet, D.I. (2011). Utilization of Souvenirs of Wood and Wildlife Products in Ecotourism: A Case Study of Destinations in Plateau State, Nigeria, Nigerian Journal of Forestry 40 (1): $15-24$

Ijeomah, H.M. and Herbert, B.C. (2012). Reality of Tourism Management: Business Viability and Tourists' Behaviour in Plateau State, Nigeria. Journal of (Cultur Revista de Cultura $e$ Turismo)6(3):18 -35

Ijeomah, H.M., Nwanegbo, O.C. and Umokoro, O. (in press). Assessment of Tourist Attractions in Okomu national park and Oguta Lake ecodestinations of Nigeria. Journal of Production Agriculture and Technology, 11(2). 
Ita, E. O; Sado, J.K; Pandogari, A and Ibitoye, B. (1985). Inventory Survey of Nigerian in Land Water and their Fishery Resources. A Preliminary Checklist of Inland Water bodies in Nigeria with Special Reference to Ponds, Lakes, Reservoirs and more Rivers. Kainji Lake Research Institutes Technical Report Series, No. 14, KLRI, New Bussa, pp. 55.

Lade, C. (2010).Developing Tourism Clusters and Networks: Attitudes to Competition along Australia's Murray River.Tourism Analysis, 15(6): 649-661.

Mac, Odo, D.S (2002). Statistics for Decision Making. Pearl Publishers Ltd., Port Harcourt:

Ministry of Tourism and Culture (2006).Farin Ruwa Waterfall. Narsarawa State Ministry of Culture and Tourism, Lafia

National Park Service (2009). National Parks in Nigeria, National Park Service, Abuja

Nwadiaro, C. S. (1985).Ichthyfauna of Lake Oguta, a shallow lake in South- eastern Nigeria. Archive Hydrobiology, 113: 463475.

Shah, K. (2000) . Tourism, the poor and other stakeholders:Asian experience. ODI Fair-Trade in Tourism Paper, ODI, .London.

Tourism Guide (2004). Tourist Attractions in Nasarawa State. Nasarawa State Ministry of Culture and Tourism, Lafia

Yamani, Y. (1961).Sampling technique: An Introduction. Prentice and Hall, Pvt Ltd,India.

\section{AUTHORS' BIOGRAPHY}

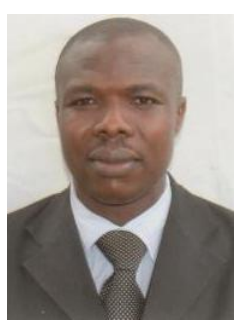

Dr. Henry Mmaduabuchi Ijeomah, holds a Master and Doctorate degrees in Wildlife and Range Management from the University of Ibadan and a Master degree in Hospitality and Tourism Management from Imo State University, Owerri. At present, he is the Head of Wildlife and Ecotourism Management Unit, and Head, Department of Forestry and Wildlife Management, University of Port Harcourt. Dr Ijeomah has taught Wildlife Management, Tourism, and Biodiversity Conservation for many years at different academic levels including Ph.D. He has designed an MSc. Programme 'Wildlife and Ecotourism Management' in the University of Port Harcourt. His present area of interest is Wildlife management and Ecotourism and he has published extensively in this field.

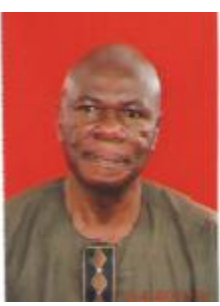

Chukwudum Innocent Conleath Okoli, is a professor of Strategic Hospitality and Tourism Management and Head, Department of Hospitality and tourism management at the Imo State University Owerri, Imo State, Nigeria. He was educated in both Nigeria and the United States of America. He earned Ph.D. in Management with specialization in Hospitality and Tourism Management at the Imo State University, Owerri and has published extensively in this field. Professor Okoli has had nearly four decades of experience in teaching and research. 